\title{
Effects of Green Silver Nanoparticles on Apoptosis and Oxidative Stress in Normal and Cancerous Human Hepatic Cells in vitro
}

This article was published in the following Dove Press journal: International Journal of Nanomedicine

\author{
May Bin-Jumah (D)' \\ Monera AL-Abdan' \\ Gadah Albasher ${ }^{2}$ \\ Saud Alarifi ${ }^{2}$ \\ 'Department of Biology, College of \\ Science, Princess Nourah Bint \\ Abdulrahman University, Riyadh, Saudi \\ Arabia; ${ }^{2}$ Department of Zoology, College \\ of Science, King Saud University, Riyadh, \\ Saudi Arabia
}

Introduction: Extensive use of metallic nanomaterials in different areas of agriculture and commercial products induce significant harmful effects on human health and the environment. In the current study, we synthesized an eco-friendly approach silver nanoparticles (AgNPs) using root extracts of Beta vulgaris L.

Methods: The synthesized green silver nanoparticles (gAgNPs) were characterized by dynamic light scattering (DLS) and high-resolution transmission electron microscope (HRTEM). The gAgNPs had a round shape and the mean size was $20-50 \mathrm{~nm}$. The cytotoxic effects of gAgNPs were determined in human hepatic normal (CHANG) and cancer (HUH7) cells by using tetrazolium salt (MTT) and lactate dehydrogenase (LDH) assays for $24 \mathrm{~h}$. Results and Discussion: It was clear from the observations of this experiment that higher concentrations of gAgNPs reduce cell viability. The production of reactive oxygen species (ROS) was evaluated by using DCFDA. The gAgNPs induced more ROS in the HuH-7 cells than in the CHANG cells. The fragmentation of DNA was evaluated by alkaline single-cell gel electrophoresis and the maximum DNA strand breakage was found at a higher concentration exposure of gAgNPs for $24 \mathrm{~h}$. It is important to notice that the $\mathrm{HuH}-7$ cells showed an increased sensitivity to gAgNPs than the CHANG cells. The apoptotic and necrotic effects of gAgNPs on both the cells were evaluated using annexin-V-FITC and propidium iodide staining. An increased count of apoptotic and necrotic cells was found following a higher concentration exposure of gAgNPs. The apoptotic protein expression in these cells due to gAgNPs exposure was determined using immunoblotting techniques and the level of $\mathrm{Bcl} 2$ was decreased. However, the expression of BAX and protein was increased in both cells.

Conclusion: Therefore, it can be concluded that higher concentrations of gAgNPs may induce significant cytotoxicity and cause DNA damage and apoptosis.

Keywords: green silver nanoparticles, cytotoxicity, CHANG and HuH-7 cells, genotoxicity, apoptosis

\section{Introduction}

Nanoparticles are an innovative class of functional materials. Silver nanoparticles (AgNPs) are extensively applied in different fields of science, such as biomedical science, including antibacterial, antiviral, anti-inflammatory, and anticancer therapies. AgNPs are being used to produce various biomedical products to prevent infection. ${ }^{1}$ The application of AgNPs has been widened due to recent advances in nanotechnology. Gulbagca et $\mathrm{al}^{2}$ (2019) reported anti-oxidant, antibacterial, antifungal, and DNA cleavage activities of biogenic silver nanoparticles. AgNPs have
Department of Zoology, College of

Science, King Saud University, BOX 2455,

Riyadh II45I, Saudi Arabia

Tel +966-14679816

Fax +96646785 I4

Email salarifi@ksu.edu.sa 
several important implications including medical diagnostics ${ }^{3}$ therapeutics, antioxidant, ${ }^{4}$ antibacterial, ${ }^{5}$ and cytotoxic ${ }^{6}$ properties. Some researchers have synthesized nanoparticles using bacteria, fungi, yeast, and plant sources. $^{7}$ Many researchers have synthesized AgNPs by using different biological materials and reported their anticancer effects as listed in (Table 1). ${ }^{8-14}$ Beta vulgaris is commonly known as red beet and cultivated as a food. Extracts of red beet showed antioxidant, antiinflammatory, antiallergic activities. ${ }^{15}$ In this study, we used root extracts of the red beet plant to synthesis ecofriendly AgNPs. AgNPs-mediated toxicity involves various mechanisms, in particular, the production of excess reactive oxygen species (ROS). At low levels, ROS regulates various cellular functions and at higher levels, it induces cell death. ${ }^{16}$ Disproportionate production of ROS induces apoptosis in a variety of human cancers including breast cancer, ovarian cancer, and lung cancer. ${ }^{17,18}$ Recent in vitro and in vivo studies have demonstrated the toxicity of AgNPs in a variety of cancerous and non-cancerous cells. ${ }^{19,20}$ Hence, we have synthesized green silver nanoparticles by using extracts of red beet (Beta vulgaris) root. Red beet is a medicinal plant used for the treatment of liver diseases and can lower the serum triglyceride level. We synthesized silver nanoparticles by using the root extracts of red beet plants. Induction of cytotoxicity of nanoparticles depends not only on their shape, surface chemistry, or size but also on the cell line studied. Erdogan et $\mathrm{al},{ }^{21}$ reported that green silver nanoparticles induced toxicity and showed anti-cancer effects with phototherapy in MCF7 cells.

Furthermore, current studies on the cytotoxic responses of the liver exposed to green silver NPs are very limited. Therefore, we selected CHANG and HuH-7cells as a model in this study. Thus, the main objective of this study was to compare the mechanism of the toxic effects of gAgNPs of similar shape and size $(30 \mathrm{~nm})$ in human liver cells.

\section{Materials and Methods Chemical and Reagents}

Green silver nanoparticle (gAgNPs) was prepared by using root extracts of Beta vulgaris L (Beet) plant. MTT [3-(4, 5-dimethylthiazol-2-yl)-2, 5-diphenyltetrazolium bromide], 2, 7-dichlorofluorescin diacetate (H2-DCFH-DA), dimethyl sulfoxide (DMSO), annexin V FITC and propidium iodide were purchased from Sigma-Aldrich (St. Louis, Missouri, United States). Dulbecco's modified Eagle's medium (DMEM), fetal bovine serum (FBS) and antibiotics were purchased from Gibco, USA.

\section{Preparation of Beet Root Extracts}

The fresh beetroot was purchased from local market and washed with running tap water and sterile double distilled water to clean soil particles, etc. Roots were cut in small pieces, grinded and filtered using mesh $(22 \mu \mathrm{m})$ and stored in refrigerator for further use.

\section{Synthesis of Silver Nanoparticles}

Ten milliliters of root extracts were mixed to $90 \mathrm{~mL}$ of silver nitrate $(1 \mathrm{mM})$ in $250 \mathrm{~mL}$ conical flask and shaked it very well. After $25 \mathrm{~min}$, the color of reaction mixture was changed in dark blackish-brown, demonstrating the formation of silver nanoparticles and reduction of $\mathrm{Ag}^{+}$ions.

\section{Physical Characterization of gAgNPs}

The size of green silver nanoparticles (gAgNPs) was determined using high-resolution transmission electron microscope (HR-TEM) (JEOL Inc., Tokyo, Japan) at an accelerating voltage $110 \mathrm{kV}$.

The mean hydrodynamic size and zeta potential of gAgNPs in $\mathrm{dH} 2 \mathrm{O}$ and culture medium were observed by

Table I Anticancer Properties of Green Synthesized AgNPs

\begin{tabular}{|l|l|l|}
\hline Biological Entity Used for Reduction & Cancer Cells Under Study & Reference \\
\hline Cleome viscosa fruit extract & Lung (A549) and ovarian (PAI) cancer cell lines & 8 \\
Annona muricata leaf extract & Human fibroblasts isolated from dermis & 9 \\
N,N,N-trimethyl chitosan chloride and & Colon cancer cell lines (HCTII6) and Mammalian cell lines (African green monkey & 10 \\
polyelectrolyte complex & kidney cell lines (VERO cells) & 11 \\
Rheum Rhabarbarum fresh stem extract & Cervical carcinoma HeLa cell line & 12 \\
Matricaria chamomilla & A549 lung cancer cells & 13 \\
Zataria multiflora leaf extract & Cervical carcinoma cells (HeLa cell line) & 14 \\
Phoenix dactylifera hair-root extract & Human breast cancer (MCF7 cell line) & \\
\hline
\end{tabular}


DLS (Nano-Zeta Sizer-HT, Malvern, UK) as described by Alarifi et $\mathrm{al}^{22}$. We have used $100 \mu \mathrm{g} / \mathrm{mL}$ for DLS measurement because this is the maximum exposure concentration used in cytotoxicity studies.

\section{Cell Culture and Treatment of Nanoparticles}

CHANG and HuH-7cells were procured from American Type Culture Collection (ATCC), USA. These cells were subcultured in DMEM culture medium supplemented with FBS $(10 \%)$ and $10,000 \mathrm{U} / \mathrm{mL}$ antibiotics at $\mathrm{CO}_{2}(5 \%)$ incubator at $37^{\circ} \mathrm{C}$. The cells at $80 \%$ confluence were subcultured into 96 well plates, 6 well plates and $25 \mathrm{~cm}^{2}$ flasks according to designed experiments.

CHANG and HuH-7 cells were sub-cultured for overnight prior to exposure to gAgNPs. The stock solution of gAgNPs was prepared in mili Q water @ $1 \mu \mathrm{g} / \mu \mathrm{L}$ and diluted according to the experimental dosage $(0-100 \mu \mathrm{g} /$ $\mathrm{mL})$. Control cells were not exposed to gAgNPs and considered as controls with each experiment.

\section{Cytotoxicity}

3-(4, 5-Dimethylthiazol-2-YI)-2,

\section{5-Diphenyltetrazolium Bromide (MTT) Assay}

The reduction of MTT into formazan crystal in CHANG and $\mathrm{HuH}-7$ cells was determined according to Alarifi et $\mathrm{al}^{23}$ method to find out the toxicity of gAgNPs in CHANG and HuH-7 cells. CHANG and HuH-7 cells $\left(1 \times 10^{4}\right.$ per well) have been cultured in 96-culture plate and exposed to different concentration of gAgNPs $(0,5,20,40$ and 100 $\mu \mathrm{g} / \mathrm{mL}$ ) of for $24 \mathrm{~h}$. After $24 \mathrm{~h}$, culture media with gAgNPs was discarded from 96 well plates and new culture media containing MTT powder $(5 \mathrm{mg} / \mathrm{mL})$ were filled $\left(100 \mu \mathrm{L} /\right.$ well) and incubated for $4 \mathrm{~h}$ at $37^{\circ} \mathrm{C}$. The produced formazan crystal was dissolved in dimethyl sulfoxide (DMSO) and optical density (OD) was determined at 570 $\mathrm{nm}$ using a micro-plate reader (Synergy-H1; BioTek, Winooski, VT, USA).

Lactate Dehydrogenase Enzyme Assay (LDH) Assay We have done LDH assay by using kit (LDH cytotoxicity assay kit 601170 Cayman chemical kit) as described by manufacturer.

\section{Evaluation of Intracellular Reactive Oxygen Species (ROS)}

Generation of intracellular ROSin CHANG and HuH-7 cells after exposure to gAgNPs $(0,5,20,40$ and $100 \mu \mathrm{g} / \mathrm{mL})$ for 24 hrs was determined according to the methods described Alzahrani et $\mathrm{al}^{24}$. Briefly, $1 \times 10^{4}$ cells were cultured in black bottom culture plate ( 96 well) and left $24 \mathrm{~h}$ for attachment in $\mathrm{CO}_{2}$ incubator at $37^{\circ} \mathrm{C}$. CHANG and $\mathrm{HuH}-7$ cells exposed to gAgNPs for $24 \mathrm{hrs}$. After treatment, the culture plates were washed with chilled PBS and $10 \mu \mathrm{M}$ DCFH-DA was added per well at $37^{\circ} \mathrm{C}$ for $1 \mathrm{hr}$. After one-hour incubation, the plate was washed and fluorescence intensity was measured at 485 $\mathrm{nm}$ excitation and $520 \mathrm{~nm}$ emissions using the micro plate reader (Synergy-H1; BioTek). Data were represented as a percent of fluorescence intensity relative to the control wells.

Another set of cells $\left(1 \times 10^{3}\right.$ cells/well in a six-well transparent plate) were analyzed for intracellular fluorescence using a fluorescence microscope (Olympus CKX 41; Olympus: Center Valley, Pennsylvania, USA), with images taken at $40 \mathrm{x}$ magnification.

\section{Preparation of Cells Extracts}

CHANG and HuH-7 cells have treated to different concentration $(0,5,20,40$ and $100 \mu \mathrm{g} / \mathrm{mL})$ of gAgNPs in $75 \mathrm{~cm}^{2}$ culture flasks for $24 \mathrm{hrs}$. The cells were washed with cold PBS and scarped by scraper (Fisher Brand Cell scrapers, Fisher Scientific USA) and cell lysis buffer [1× $20 \mathrm{mM}$ Tris- $\mathrm{HCl}$ ( $\mathrm{pH} 7.5), 150 \mathrm{mM} \mathrm{NaCl}, 1 \mathrm{mM} \mathrm{Na}_{2}$ EDTA, 1\% Triton, $2.5 \mathrm{mM}$ sodium pyrophosphate] were added in tube for $30 \mathrm{~min}$ at $4^{\circ} \mathrm{C}$. After incubation, the cells were centrifuged at $15,000 \mathrm{rpm}$ at $4^{\circ} \mathrm{C}$ and supernatant was collected and retained on ice for other tests. The quantity of protein in cell lysate was measured by Bradford method. ${ }^{25}$

\section{LPO Assay}

LPO (lipid peroxide) level was evaluated by determining the development of malondialdehyde (MDA) using the method of Ohkawa et $\mathrm{al}^{26}$. One hundred microliter cell lysate was mixed with $1.9 \mathrm{~mL}$ sodium phosphate buffer $(0.1 \mathrm{M}, \mathrm{pH} 7.4)$ and incubated for $60 \mathrm{~min} 37^{\circ} \mathrm{C}$. After incubation TCA $(5 \% \mathrm{w} / \mathrm{v})$ was added and centrifuged at $3000 \mathrm{~g}$ for $10 \mathrm{~min}$ at room temperature to obtain supernatant. The supernatant was mixed with $1 \mathrm{~mL}$ TBA (1\%) and put in water bath at $100^{\circ} \mathrm{C}$ for $30 \mathrm{~min}$. The absorbance of cooled mixture was observed at $532 \mathrm{~nm}$ and was converted to MDA and expressed in terms of $\mathrm{mM} \mathrm{MDA} / \mathrm{mg}$ protein.

\section{GSH Assay}

The evaluation of total glutathione content (GSH/GSSG) was done using a colorimetric test kit (ab156681). The 
total glutathione quantity was measured by comparison with the predetermined glutathione standard curve. Data were expressed as nM (GSH/GSSG)/mg protein.

\section{Evaluation of Mitochondrial Membrane Potential (MMP)}

CHANG and HuH-7 cells were cultured in clear bottom black 96-well plate and incubated at $37^{\circ} \mathrm{C}, 5 \% \mathrm{CO} 2$ and 95\% humidity for 24 hrs to allow for cell attachment. After incubation, medium was discarded from plate and different concentration $(0,5,20,40$ and $100 \mu \mathrm{g} / \mathrm{mL})$ of gAgNPs exposed to plate for $24 \mathrm{hrs}$. After treatments, the NPs were removed and plates were washed three-time Hank's balanced salt solution. Then JC-1 $(10 \mu \mathrm{M})$ was added per well and plates were put for $60-70 \mathrm{~min}$ at $37^{\circ} \mathrm{C}$. After dye incubation, the dye was removed from the plates and the plates were washed two times with chilled HBSS. Fluorescence was evaluated at excitation/emission 485/ $580 \mathrm{~nm}$ and then at excitation/emission $485 / 530 \mathrm{~nm}$ using a fluorescence plate reader (Synergy Biotech, USA).

To confirm the compromisation of MMP in CHANG and HuH-7 cells, plates were also used to capture fluorescence images from fluorescence microscopy (Nikon Eclipse TE 300). Excitation of JC-1 was at $450-480 \mathrm{~nm}$ and emission was measured using a long pass 520 filter, which allowed seeing both the green and red florescence intensity at the same time.

\section{Condensation of Chromosome in CHANG and $\mathrm{HuH}-7$ Cells}

CHANG and HuH-7 cells were cultured in six-well plates and added to various concentrations $(0,5,20$, and $40 \mu \mathrm{g} /$ $\mathrm{mL}$ ) of gAgNPs for $24 \mathrm{hrs}$. After exposure to gAgNPs the condensation of chromosome in cells examined by using confocal microscope after staining Hoechst $33342(10 \mu \mathrm{L})$ and propidium iodide (PI) $(10 \mu \mathrm{L})$ stains.

\section{Evaluation of Caspase-3}

Caspase-3 enzymes play a significant role in cell death. Caspase- 3 enzymes were determined in gAgNPs $(0,5,20$, and $40 \mu \mathrm{g} / \mathrm{mL}$ ) exposed and unexposed CHANG and HuH-7 cells by using Bio-Vision colorimetric assay kits.

\section{Flow Cytometric Analysis}

The apoptotic and necrotic CHANG and $\mathrm{HuH}-7$ cells after exposure to gAgNPs $(0,5,20$, and $40 \mu \mathrm{g} / \mathrm{mL})$ for $24 \mathrm{hrs}$ were determined through flow cytometer (BectonDickinson Immuno cytometry Systems, Sunnyvale, CA,
USA) by using Annexin V-FITC/PI staining. Cells were accumulated by trypsinization, and washed with PBS and re-suspended in binding buffer at a concentration of $10^{6}$ cells/mL. Annexin V-FITC $(5 \mu \mathrm{L})$ and PI $(5 \mu \mathrm{L})$ was mixed to cell suspension $(500 \mu \mathrm{L})$ and incubated for 30 $\mathrm{min}$ at the dark at room temperature. Then cells were screened by flow cytometry (Becton-Dickinson Immuno cytometry Systems, Sunnyvale, CA, USA). Fluorescence emitted by Annexin V bound FITC and DNA-bound propidium iodide in each event was detected as red fluorescence, respectively. Results were analyzed by FACS Diva 6.1.2 software.

\section{DNA Fragmentation Assay}

DNA fragmentation after exposure to gAgNPs in both cells were examined applying alkaline single-cell gel electrophoresis assay according to Ali et $\mathrm{al}^{27}$. This is a visual and sensitive technique for evaluating DNA strand breakage in CHANG and HuH-7 cells. The damage is expressed by an increase of DNA fragments that have migrated out of the cell nucleus during electrophoresis and formed an image of a DNA in comet tail length (\% of tail DNA) and olive tail moment. A total of 50 cells on each slide were counted according to the intensity of fluorescence in the tail. DNA damage was expressed as percentage tail DNA and olive tail moment by using a Carl Zeiss (AXIO), Imager M1 microscope connected to a computer with Comet Imager V.2.0.0 software for comet analysis.

\section{Western Blot Assay}

The two liver cells (CHANG and HuH-7 cells) were scrapped in RIPA buffer (ab156034), after which the cell were centrifuged at $13,000 \mathrm{rpm}, 4^{\circ} \mathrm{C}$ for $30 \mathrm{~min}$ and supernatant were transfer in new tube for further study. The proteins $(20 \mu \mathrm{g})$ were separated on TGX stain free gel and transferred to a polyvinylidene fluoride (PVDF) membrane (Bio Rad, Laboratories Inc., Berkeley, CA, USA). The membrane was then incubated with mouse monoclonal antibody against $\beta$-actin (1:12,000 dilutions, Abcam, Cambridge, UK), Bax (1:1000 dilutions, Antibodies-online), Bcl-2 (1:500 dilutions, Santa Cruz) overnight at $4^{\circ} \mathrm{C}$. The horseradish peroxidase (HRP)-conjugated goat anti-mouse IgG (H + L) antibody (1:2000 dilutions Bio Rad) was used as a secondary antibody. Immuno-reactive bands were detected using an EZ west Lumi plus (ATTO corporation, Tokyo, Japan), which is a chemiluminescent substrate to detect HRP on Western blotting membrane. The luminescence intensity (optical density) of the target protein bands was 


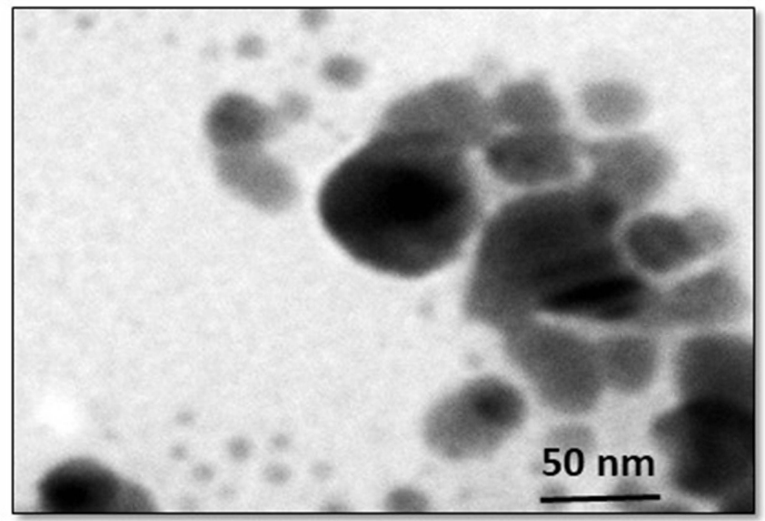

A

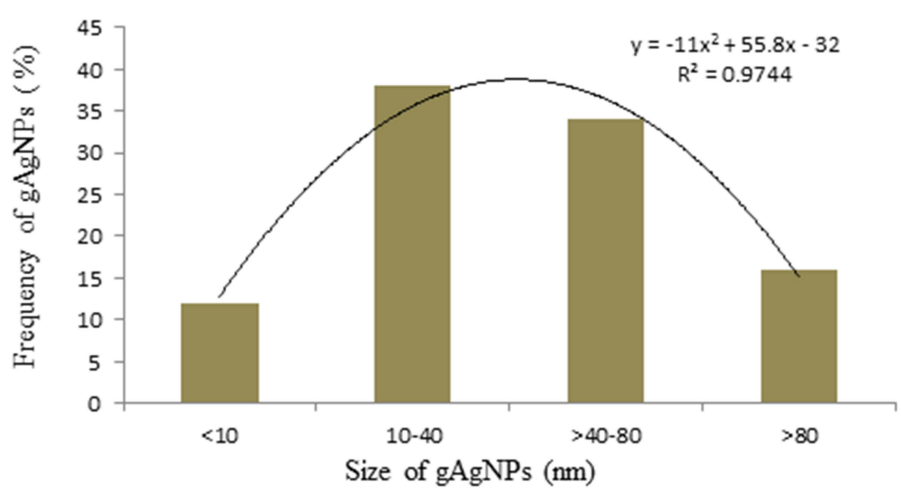

B

Figure I (A) TEM image of green silver nanoparticles (gAgNPs) (B) Distribution green silver nanoparticles (gAgNPs) size (\%).

quantified using Lumino Graph 2 (ATTO Corporation). All protein expression levels were normalized to the levels of $\beta$ actin protein expression in each band.

\section{Statistical Analysis}

All experiments were run minimum three times, and data presented as average \pm standard error $( \pm \mathrm{SE})$. Data from the experiments were statistically analyzed by one-way analysis of variance (ANOVA) followed by a post hoc Dunnett's test using the Graph Pad prism 5.01 software (Graph Pad Software Inc., San Diego, CA, USA). A p-value $<0.05$, 0.01 , was considered statistically significant and highly significant in this data, respectively.

\section{Results}

\section{Physiochemical Characterization of gAgNPs}

The gAgNPs was characterized by applying by HR-TEM and DLS methods. The TEM image of gAgNPs was presented in Figure 1A. The mean diameter of gAgNPs with spherical shape was $52.4 \pm 3.6 \mathrm{~nm}$. The hydrodynamic size of gAgNPs in water and culture media were $122 \pm 2.0 \mathrm{~nm}$ and $160 \pm 3 \mathrm{~nm}$. The zeta-potential of NPs in water and culture media were $\sim 11.4 \pm 2.6 \mathrm{mV}$ and $\sim 9.1 \pm 2.4 \mathrm{mV}$ (Table 2).

\section{Cytotoxicity}

The cytotoxic response of gAgNPs on CHANG and $\mathrm{HuH} 7$ cells was assessed by MTT and LDH assays and cytotoxicity results were shown in Figure $2 \mathrm{~A}$ and $\mathrm{B}$ ). The gAgNPs showed more adverse effects on $\mathrm{HuH} 7$ cells than CHANG cells. The gAgNPs produced cytotoxicity in concentration dependent manner. The maximum cytotoxic level of gAgNPs in CHANG cells was $70.5 \%$ and whereas it was $54.9 \%$ for $\mathrm{HuH} 7$ cells. Some researchers reported that cell viability up to $50 \%$ and onwards demonstrate the nanoparticle is non-cytotoxic, whereas less than $50 \%$ cell viability demonstrate the NPs are cytotoxic. $^{28}$ The different types of cells showed variation in LDH activity. ${ }^{29}$ In this experiment the release of LDH enzyme in HuH-7 cells was more than CHANG cells. Thus it was confirmed that gAgNPs was cytotoxic for HuH-7 cells and result of LDH test was agreement with the finding of MTT test (Figure 2B).

\section{Oxidative Stress Biomarkers}

The generation of ROS in CHANG and HuH-7 cells after treatment of gAgNPs was determined and it was generated as concentration dependent manner. Oxidative stress includes lipid peroxidation, glutathione and oxidative damage to nuclear materials and proteins at cellular levels. The generation of ROS was measured by using DCFDA and it was oxidized in cells and formed DCF fluorescent

Table 2 DLS Measurements of Nanoparticle Size and Zeta Potential to Compare the Dispersion Characteristics of Particles in Simplified and in vitro Biological Representative Media

\begin{tabular}{|l|l|l|l|}
\hline $\begin{array}{l}\text { Nano } \\
\text { Powder }\end{array}$ & Dispersion Media & $\begin{array}{l}\text { DLS Mean } \pm \\
\text { S.E. }(\mathbf{n m})\end{array}$ & $\begin{array}{l}\text { Zeta Potential } \pm \\
\text { S.E. }(\mathrm{mV})\end{array}$ \\
\hline $\begin{array}{l}\text { gAgNPs } \\
\geq 100 \mathrm{~nm}\end{array}$ & Milli-Q- $\mathrm{H}_{2} \mathrm{O}$ & $122 \pm 2.0$ & $-11.4 \pm 2.6$ \\
\cline { 2 - 4 } & $\begin{array}{l}\text { DMEM/un- } \\
\text { supplemented media }\end{array}$ & $160 \pm 3$ & $-9.1 \pm 2.4$ \\
\hline
\end{tabular}

Notes: Data represent the mean \pm standard error of the mean (S.E) of threeindependent experiments, carried out at $24^{\circ} \mathrm{C}$, with each experimental mean generated from triplicate measurement of each sample $(n=3)$. 


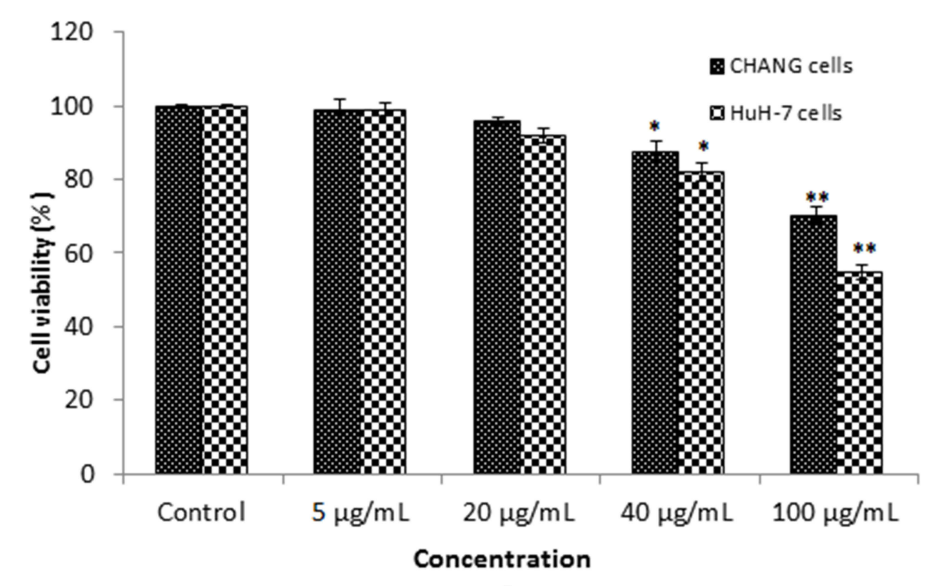

A

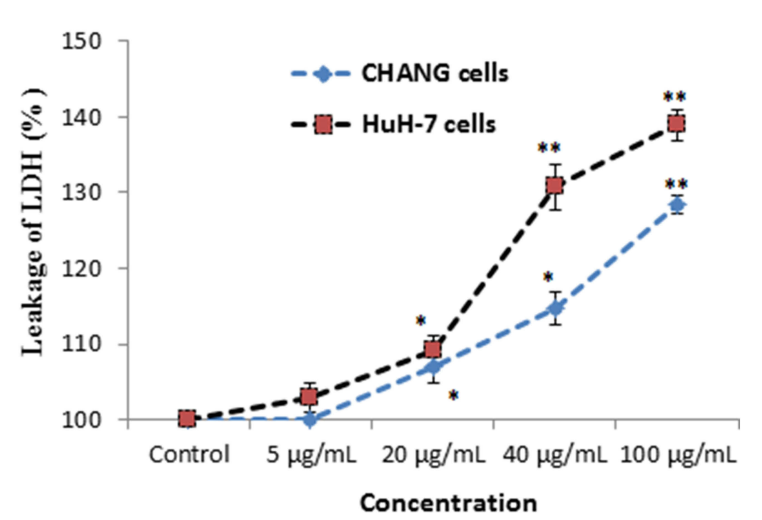

B

Figure 2 Cytotoxicity of gAgNPs on CHANG and HuH-7 cells for 24 hrs, as evaluated by (A). MTT (B). LDH assays. Each value represents the mean \pm SE of three experiments. $n=3, * p<0.05, * * p<0.01$ vs control.

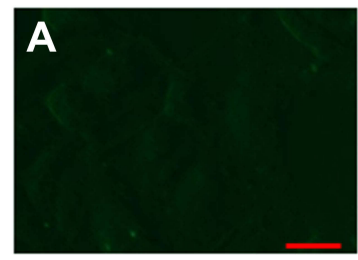

\section{D}
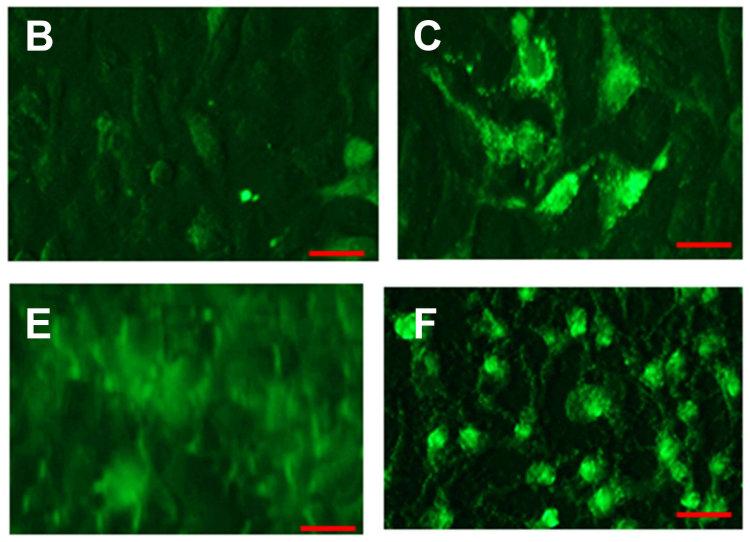

$\left.\begin{array}{c}200 \\ 150\end{array}\right] \begin{aligned} & \text { CHANG cells } \\ & \text { [HuH-7 cells }\end{aligned}$

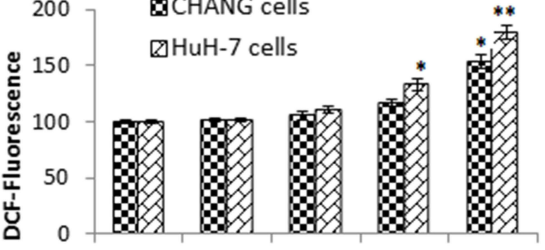

Control $5 \mu \mathrm{g} / \mathrm{mL} 20 \mu \mathrm{g} / \mathrm{m} 40 \mu \mathrm{g} / \mathrm{m} \omega 0 \mu \mathrm{g} / \mathrm{mL}$

Concentration

G

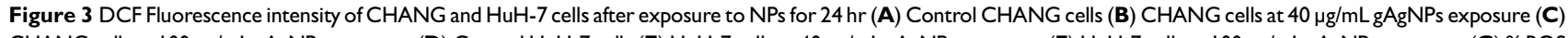
CHANG cells at $100 \mu g / m L$ gAgNPs exposure (D) Control HuH-7 cells (E) HuH-7 cells at $40 \mu g / m L$ gAgNPs exposure (F) HuH-7 cells at I00 $\mu g / m L$ gAgNPs exposure (G) \% ROS generation due to NPs exposure to cells. Each value represents the mean \pm SE of three experiments. $*_{p}<0.05$ and $* *_{p}<0.0$ Ivs. control. Scale bar is $200 \mu \mathrm{m}$.

compound. We have observed high intensity of green fluorescence in $\mathrm{HuH}-7$ cells than CHANG cells (Figure 3A-F). Percentage of intracellular generation of ROS was $153.8 \%$ and $180 \%$ in CHANG and $\mathrm{HuH}-7$ cells at higher concentration of gAgNPs exposure, respectively (Figure $3 \mathrm{G}$ ).

The other oxidative biomarkers such as LPO and GSH were determined in these cells. The level of glutathione was decreased (Figure 4B) and lipid peroxide was increased in $\mathrm{HuH}-7$ cells than CHANG cells (Figure 4A).

\section{MMP}

We have measured loss of MMP in CHANG and HuH-7 cells at different concentration of gAgNPs for 24 applying the dye, JC-1. Red aggregates were indicative of intact mitochondrial membrane potential (MMP) were predominant in cells at exposure of lower concentration of gAgNPs $(5 \mu \mathrm{g} / \mathrm{mL})$ (Figure 5C). The cells treated with high concentration (100 $\mu \mathrm{g} / \mathrm{mL}$ ) decrease red aggregate and increase green aggregate were indicating loss of MMP (Figure 5A and B). Our findings agreement with finding of Bova et al, ${ }^{30}$ for loss of MMP in HepG2 cells due to troglitazone. The MMP was decreased in a dose-response manner (Figure 5).

\section{Apoptosis and Necrosis in Cells}

We have determined the activity of caspase- 3 in CHANG and $\mathrm{HuH}-7$ cells. Activity of caspase-3 was found more in $\mathrm{HuH}-7$ cells than CHANG cells (Figure 6G). The chromosome condensation was observed by using DAPI and more condensed chromatin was found in $20 \mu \mathrm{g} / \mathrm{mL}$ and $40 \mu \mathrm{g} / \mathrm{mL}$ gAgNPs exposed CHANG (Figure 6B and $\mathrm{C}$ ) and $\mathrm{HuH}-7$ cells 


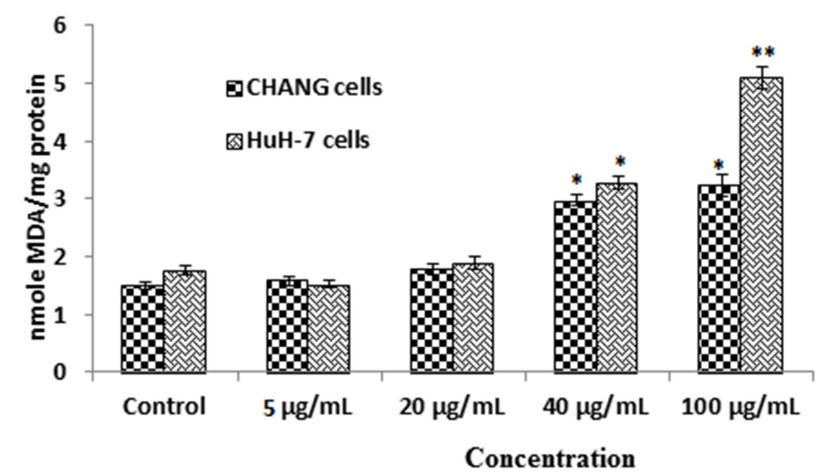

A

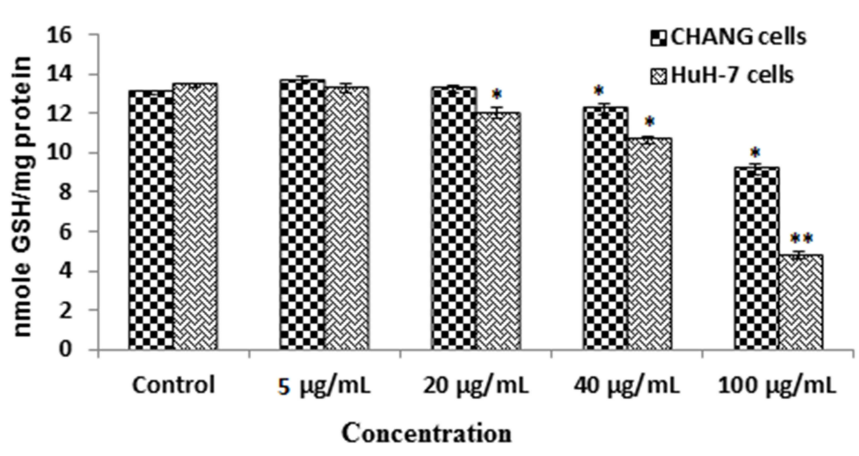

B

Figure 4 After exposure of gAgNPs on CHANG and HuH-7 cells for 24 hrs (A). Levels of LPO (B). GSH in cells. Each value represents the mean \pm SE of three experiments. $*_{p}<0.05$ and ${ }^{* *} p<0.01$ vs control.
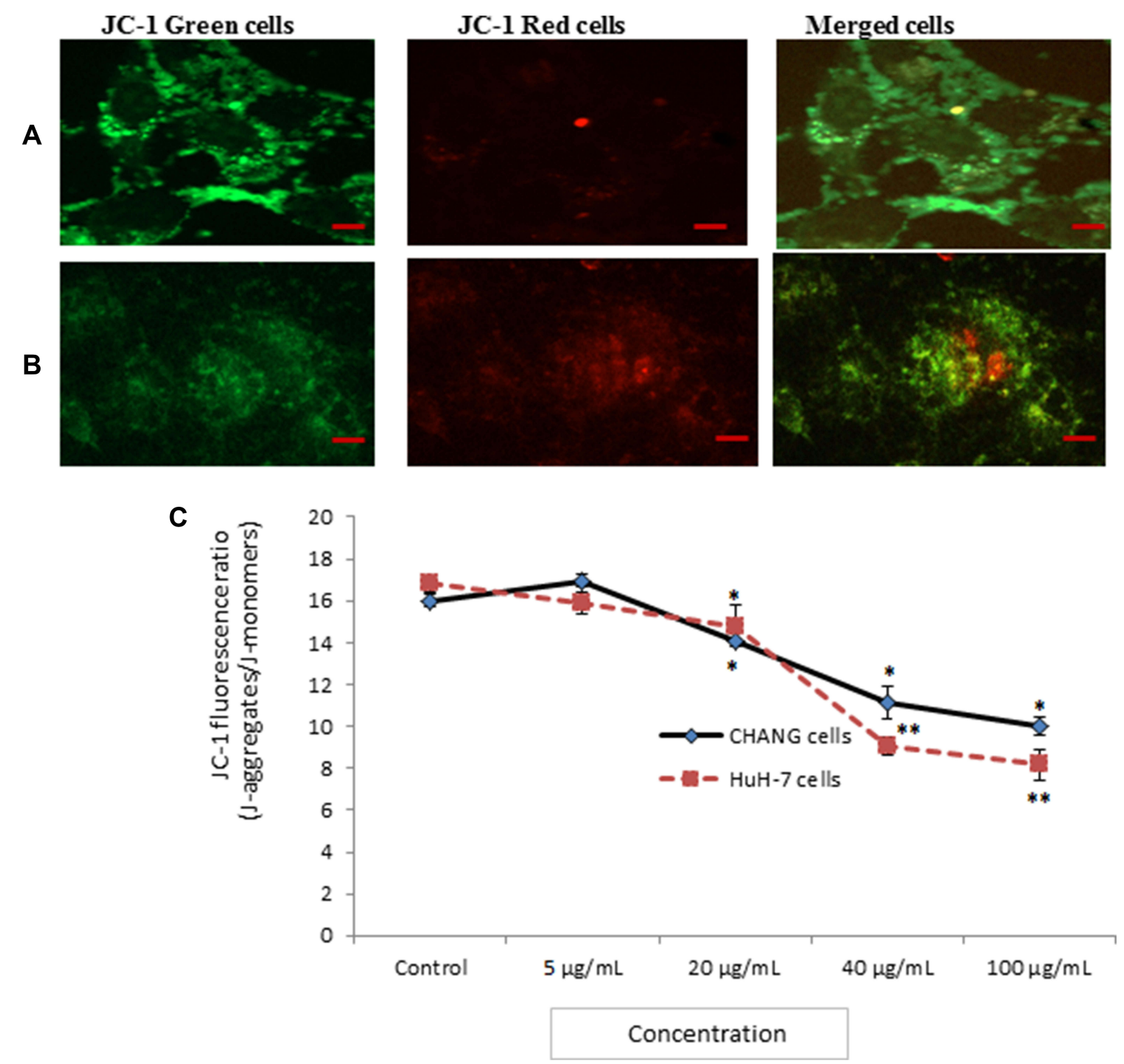

Figure 5 Photomicrograph of JC-I fluorescence intensity in CHANG cells (A) and HuH-7 cells (B) after exposure to gAgNPs (C). JC-I fluorescence ratio as marker of MTP loss. Each value represents the mean \pm SE of three experiments. ${ }^{*} p<0.05$ and ${ }^{* *} p<0.01$ vs control. Scale bar is $20 \mu \mathrm{m}$. 

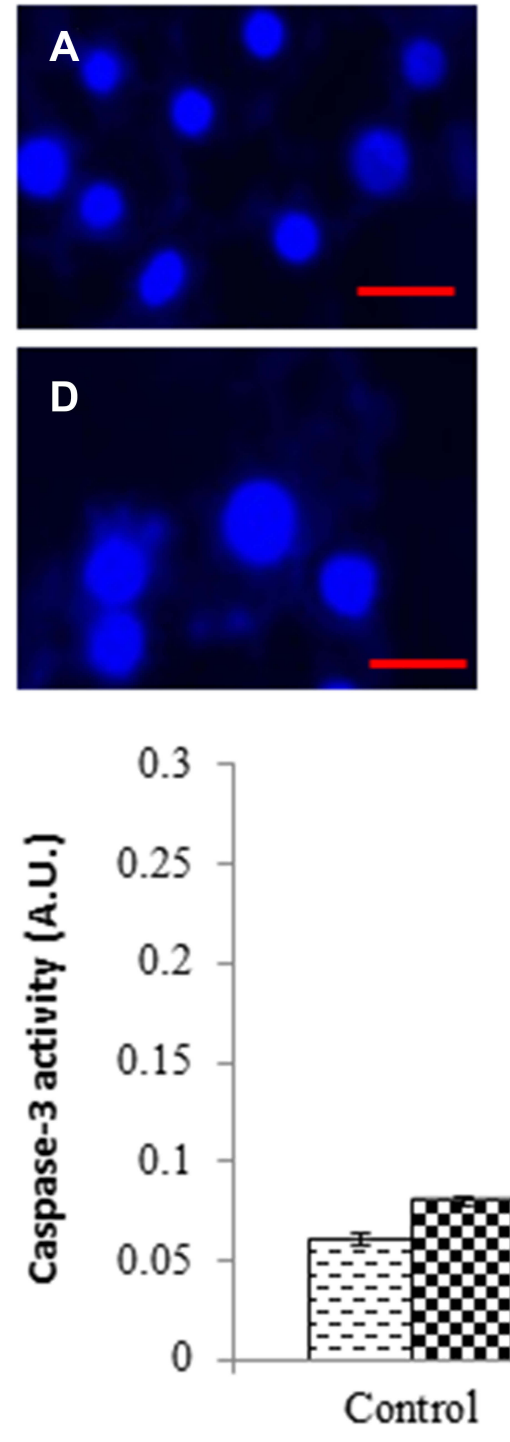
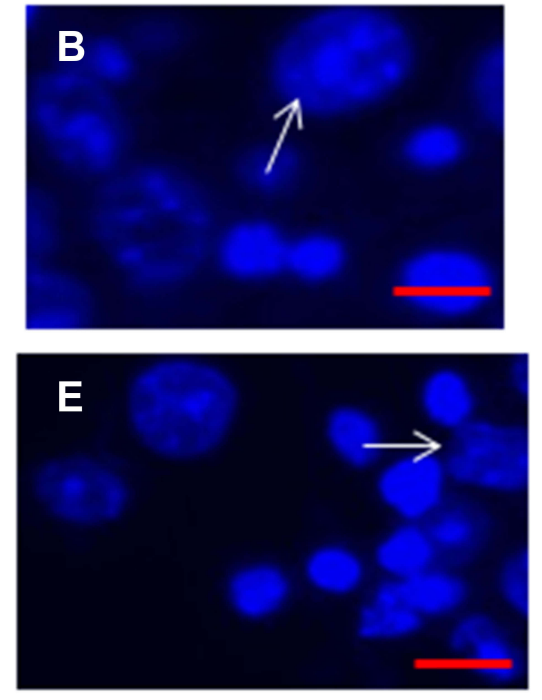
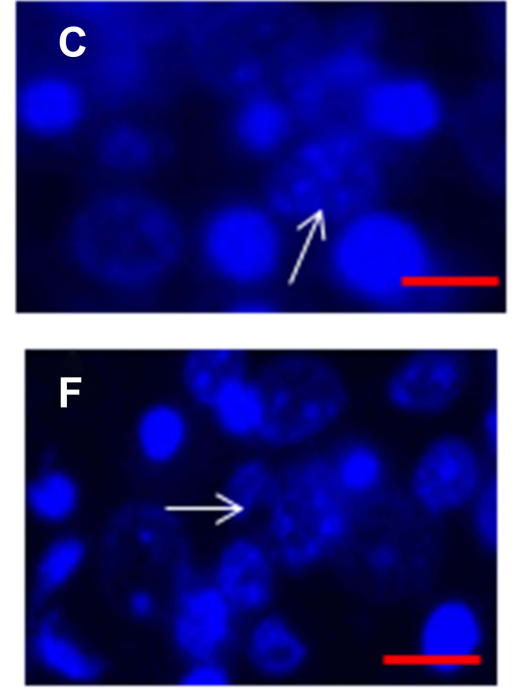

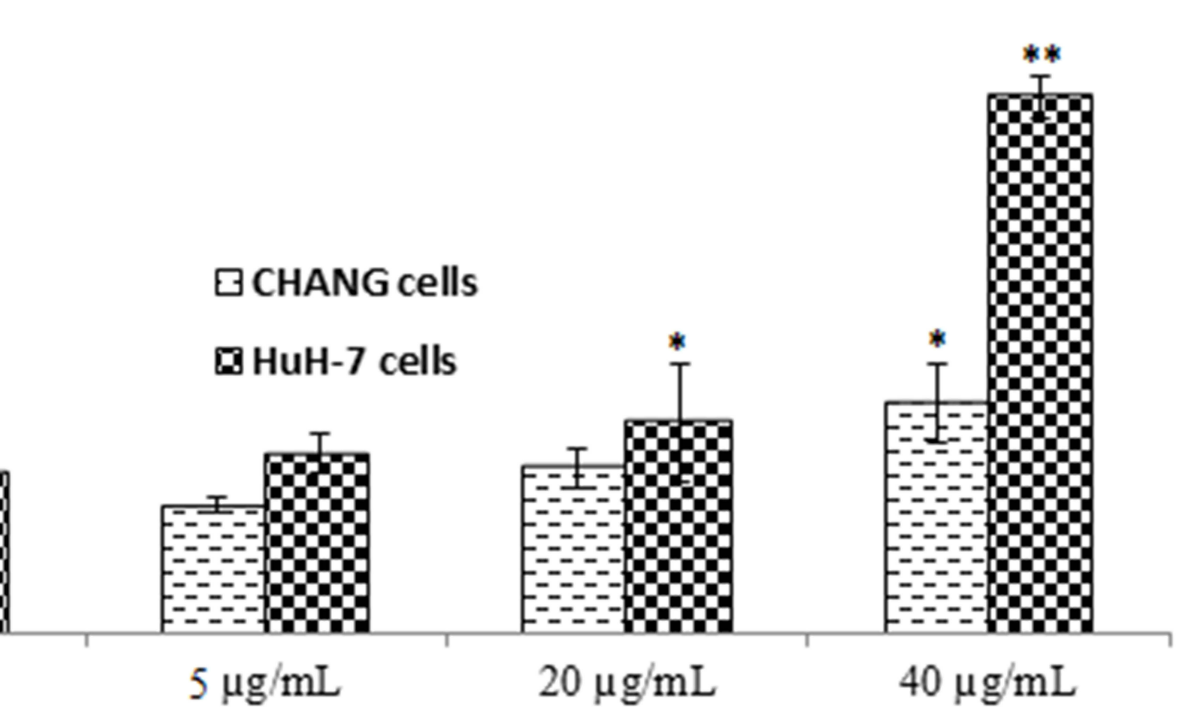

\section{Concentration}

G

Figure 6 Chromosomal condensation (A). Control CHANG cells (B). CHANG cells exposed at $20 \mu g / \mathrm{mL}$ gAgNPs (C). CHANG cells exposed at $40 \mu g / \mathrm{mL}$ gAgNPs (D).

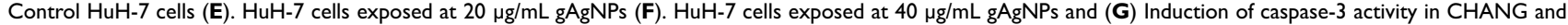
$\mathrm{HuH}-7$ cells after exposure to gAgNPs for $24 \mathrm{hrs}$. Each value represents the mean $\pm \mathrm{SE}$ of three experiments. ${ }^{*} p<0.05$ and ${ }^{*} p p<0.0 \mathrm{l}$ vs control. Arrow indicates fragmented chromosome. Scale bar is $200 \mu \mathrm{m}$.

(Figure 6E and F) as compared to control cells (Figure 6A and D), respectively.

Figure 7 represents the typical fluorescence activated cell sorting (FACS) photomicrograph. The statistical analysis of early and late apoptotic cells was determined by (FACS) as shown in Figure 7A-E. The cell histogram revealed that no cytotoxic effects of gAgNPs at lower concentrations. The gAgNPs induced high toxicity towards HuH-7 cells. Even at the higher concentration of gAgNPs $(40 \mu \mathrm{g} / \mathrm{mL})$, the early and late apoptosis rate was
$24.42 \%$ and $26.46 \%$, respectively, compared with that of the control group (Figure 7E).

\section{DNA Damage}

The fragmentation of DNA in both cells after exposure to gAgNPs was measured in the form of percentage tail DNA and olive tail moment (Figure 8A-F). The gAgNPs induced DNA damage in both cells in concentration dependent manner but higher DNA damage was seen in HuH-7 cells than CHANG cells (Figure 8A and B). 


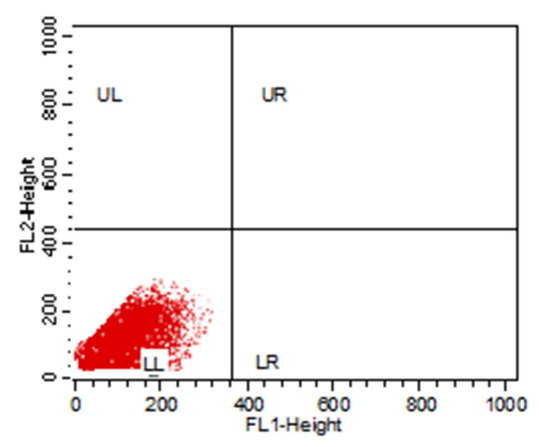

A gAgNPs $(0 \mu \mathrm{g} / \mathrm{ml})$ CHANG cells

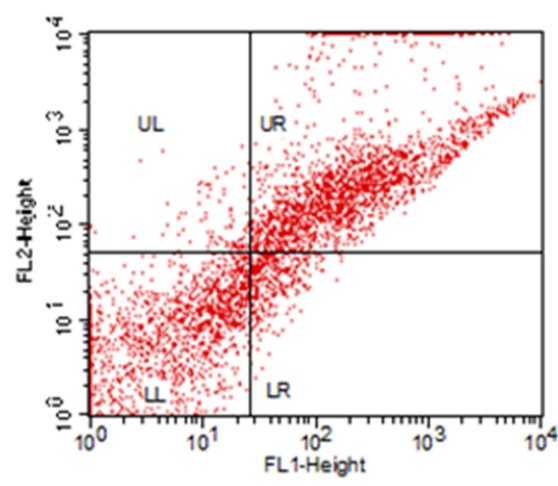

D

gAgNPs $(40 \mu \mathrm{g} / \mathrm{ml}) \mathrm{HuH}-7$ cells

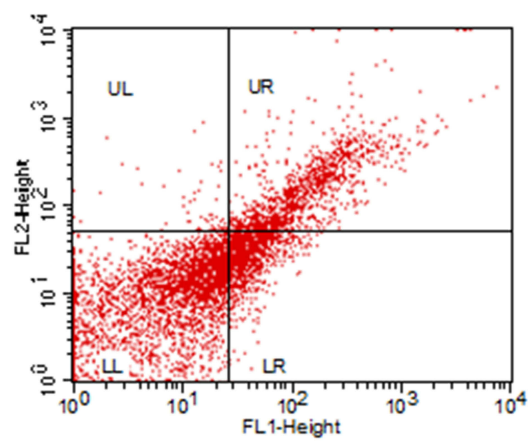

B

gAgNPs $(40 \mu \mathrm{g} / \mathrm{ml})$ CHANG cells

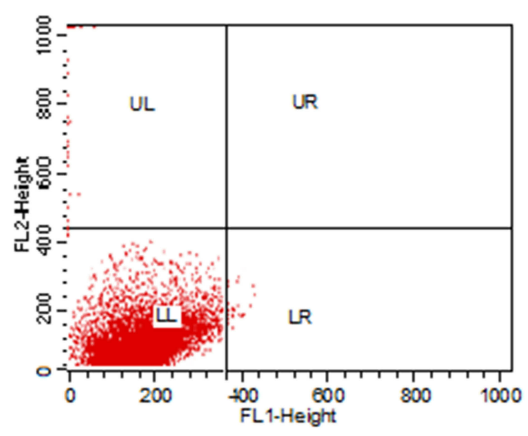

C

gAgNPs $(0 \mu \mathrm{g} / \mathrm{ml})$ HuH-7 cells

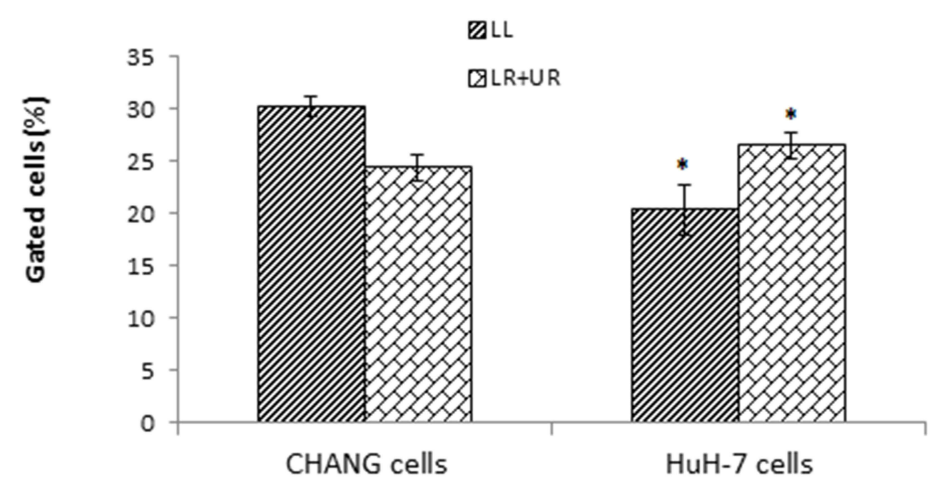

$\mathbf{E}$

Figure 7 The fluorescence scatter diagram after exposure to gAgNPs $(40 \mu \mathrm{g} / \mathrm{mL})$ to cells $(\mathbf{A})$. Control CHANG cells (B). CHANG cells exposed at $40 \mu g / \mathrm{mL} g A g N P s($ C). Control HuH-7 cells (D). HuH-7 cells exposed at $40 \mu \mathrm{g} / \mathrm{mL}$ gAgNPs and (E) Induction of early and late apoptotic cells (\%) after exposure to gAgNPs (40 $\mu \mathrm{g} / \mathrm{mL}$ ) for $24 \mathrm{hrs}$. Each value represents the mean $\pm S E$ of three experiments. ${ }^{*} p<0.05$ vs control. FL-I Height and FL-2 Height represents Annexin-V-FITC and PI staining cells, respectively. $\mathrm{LL}$ - living cells (Annexin- $\mathrm{V}^{-} / \mathrm{PI}^{-}$stained), LR - Early apoptotic cells (Annexin- $\mathrm{V}^{+} / \mathrm{PI}^{-}$stained), UL - Necrotic cells (Annexin- $\mathrm{V}^{-} / \mathrm{PI}^{+}$stained), UL - Late apoptotic cells (Annexin$\mathrm{V}^{+} \mathrm{PI}^{+}$stained).

\section{Altered Expression of Apoptotic Protein}

To determine the expression of apoptotic protein in CHANG and HuH-7 cell by gAgNPs was evaluated by Western blot analysis (Figure 9). In CHANG cells, gAgNPs induced dose dependent decrease in Bcl2 protein expression (Figure 9A) and increased expression of bax, proteins (Figure 9A). HuH-7 cells induced similar effects, leading to a significant decrease in Bcl2 and increase in bax, protein expression (Figure 9B). As in observation, there was more expression of apoptotic protein in HuH-7 cells than CHANG cells (Figure 9C).

\section{Discussion}

The most significant use of nanotechnology is the upg rade of human health through medical innovations. ${ }^{31}$ Nanotechnology is an inventive field of science involving the higher application of new materials. We used red beet extracts for the synthesis of silver nanoparticles. The synthesized silver nanoparticles had a spherical shape and the size ranged from 5 to $100 \mathrm{~nm}$ (Figure 1). Some researchers reported that the size of synthesized nanoparticles depends upon the plant extract volume. ${ }^{32}$ Green technology is a set of principles or rather a chemical philosophy that encourages the design of products and processes that reduce or eliminate the use and generation of hazardous substances. ${ }^{33}$ This indicates that most of the microspheres are produced in the products except when red beet extracts are used and during organic molecule capping on the surface of AgNPs. ${ }^{34}$ Based on the reported studies, it is clear that silver nanoparticles are extensively used as antibacterial and antimicrobial agents. ${ }^{35}$ In particular, AgNP-based nano-systems were assessed as suitable carriers of various therapeutic molecules, including anti-inflammatory, ${ }^{36}$ antioxidant, ${ }^{37}$ antimicrobial, ${ }^{38}$ anticancer $^{39}$ substances. Nowadays, biosynthesized metallic nanoparticles using plant extracts have drawn more attention because of being a simple and viable alternative against chemical and physical methods with a potential application in the field of nanomedicine. Silver nanoparticles were synthesized using Piper longum fruit and showed antibacterial and cytotoxic effects. ${ }^{40}$ In this experiment, we determined the cytotoxic and genotoxic potentials of the gAgNPs in 


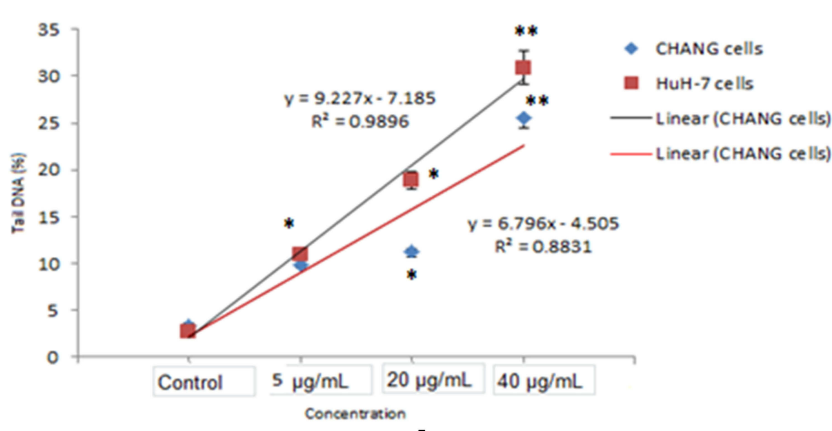

A
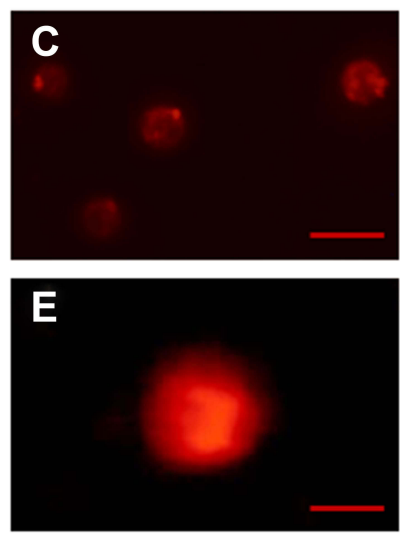

$\mathbf{F}$

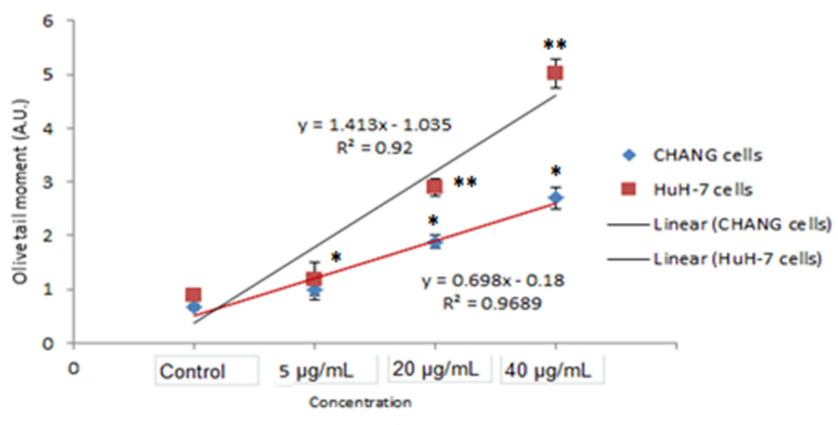

B

Figure 8 Genotoxic effect of gAgNPs exposure to CHANG and HuH-7 cells (A). Tail DNA (\%) (B). Olive tail moment. DNA damage photomicrograph of cells due to

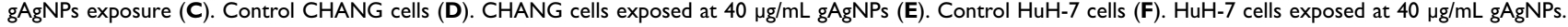
Each value represents the mean \pm SE of three experiments. ${ }^{*} \mathrm{p}<0.05$ and $* * \mathrm{p}<0.01$ vs control. Scale bar is $50 \mu \mathrm{m}$.

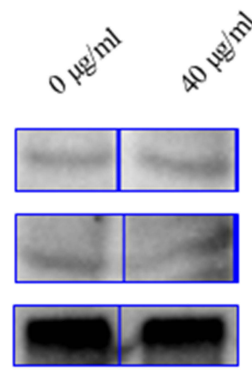

A CHANG cells
$\operatorname{Bax}$

$\mathrm{Bcl} 2$

$\beta$-actin
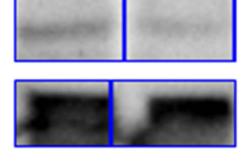

B $\mathrm{HuH}-7$ cells

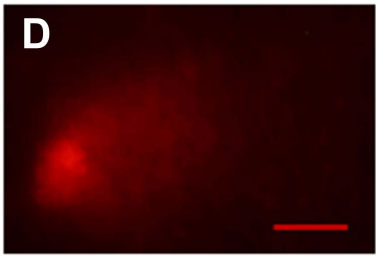

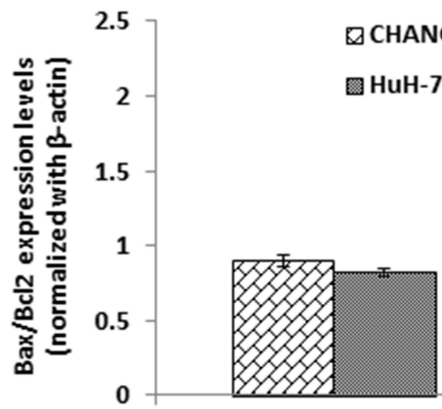

$0 \mu \mathrm{g} / \mathrm{mL}$

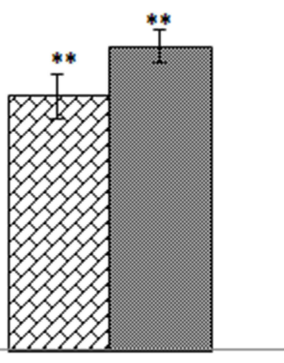

$40 \mu \mathrm{g} / \mathrm{mL}$

\section{Concentration}

C

Figure 9 Expression of pro and anti-apoptotic proteins as evaluated by immuno blotting for 24 hrs (A) CHANG cells (B) HuH-7 Cells (C) Densitometry analysis of relative protein level of $\mathrm{Bax} / \mathrm{Bcl} 2$ ratio. Each value represents the mean $\pm \mathrm{SE}$ of three experiments. $\mathrm{n}=3, * * p<0.0 \mathrm{I}$ vs control.

CHANG and HuH-7cells. The gAgNPs reduced the cell vitality of these cells after exposure to gAgNPs. The gAgNPs induced more cytotoxic effects on the HuH-7 than on the CHANG cells. The morphological alterations of these cells were evaluated by $\mathrm{AO} / \mathrm{EtBr}$ staining and these changes were correlated to gAgNPs cytotoxicity. The synthesized silver nanoparticles were able to induce fragmentation of the nucleus in the cells. Mousavi et $\mathrm{al},{ }^{41}$ reported that gAgNPs synthesized by using the leaf extracts of Artemisia turcomanica induced cytotoxic and apoptotic effects on gastric cancerous cells. Nanoparticles induce free radicals, which may damage the cells through oxidative stress mechanism. The generation of intracellular ROS deteriorates the lipid membrane of the target cells by the formation of 
malondialdehyde molecule and this is known as lipid peroxidation (LPO). ${ }^{42}$ In this study, a more prominent lipid peroxidase activity was observed in the HuH-7 than CHANG cells. ROS has been linked through a different mechanism such as damaging nuclear components (DNA and RNA) and protein, interference of cellular signaling pathways, and alteration in the gene expression ultimately leading to the stoppage of cell growth. $^{42}$ Treatment of CHANG and $\mathrm{HuH}-7$ cells with gAgNPs revealed concentration-dependent toxic effects on mitochondrial injury and DNA damage because of oxidative stress. Interestingly, among these two-cell types, the $\mathrm{HuH}-7$ cells were more sensitive than the CHANG cells. To confirm whether cell proliferation was inhibited by the apoptotic response, we investigated the apoptotic cells by annexinV-FITC and PI staining after exposure to gAgNPs. The genotoxic potential of gAgNPs was determined by using the comet assay and higher DNA damage was found at the maximum concentration of AgNPs exposure. We measured the LPO and glutathione levels, biomarkers of oxidative stress, in both the cells after treatment with NPs.

This study indicates that gAgNPs is an inducer of apoptosis in the liver cells, although its effect takes place more slowly than the DNA-damaging nanoparticles and after a long dormant time. However, mitochondria are the main source of ROS generation. ${ }^{43}$ Some researchers reported that the increased ROS generation in Rett mice was accompanied by increased mitochondrial activity. ${ }^{4,44}$ MMP contributes to the systemic oxidative burden and oxidative tissue damage in $\mathrm{CHANG}$ and $\mathrm{HuH}-7$ cells.

The gAgNPs-induced apoptosis was initiated by the activation of caspase-3, which was observed at 20 and $40 \mu \mathrm{g} / \mathrm{mL}$ nanoparticle exposure by evaluation of the caspase- 3 activity by ELISA and immunoblotting. Activation of caspase- 3 was accompanied by the down-regulation of $\mathrm{Bcl} 2$ and the upregulation of Bax and p53 proteins. All these events led to the appearance of the morphological signs of apoptosis, which were observed in more cells after exposure to NPs.

It was significant to note that $\mathrm{HuH}-7$ cells were more susceptible to gAgNPs than the CHANG cells. In the future, we will investigate the mechanisms of toxicity due to gAgNPs in in vivo experiments.

\section{Acknowledgment}

This research was funded by the Deanship of Scientific Research at Princess Nourah Bint Abdulrahman University, through the Research Funding Program (Grant No\# FRP-1440-4).

\section{Disclosure}

The authors report no conflicts of interest in this work.

\section{References}

1. Chen X, Schluesener HJ. Nanosilver: a nano-product in medical application. Toxicol Lett. 2008;176(1):1-12. doi:10.1016/j. toxlet.2007.10.004

2. Gulbagca F, Ozdemir S, Gulcan M, Sen F. Synthesis and characterization of Rosa canina-mediated biogenic silver nanoparticles for anti-oxidant, antibacterial, antifungal, and DNA cleavage activities. Heliyon. 2019;5(12):e02980. doi:10.1016/j.heliyon.2019.e02980

3. El-Sayed IH, Huang X, El-Sayed MA. Surface plasmon resonance scattering and absorption of anti-EGFR antibody conjugated gold nanoparticles in cancer diagnostics: applications in oral cancer. Nano Lett. 2005;5:829-834. doi:10.1021/n1050074e

4. Lim YY, Murtijaya J. Antioxidant properties of Phyllanthus amarus extracts as affected by different drying methods. LebTechnol. 2007;40:1664-1669.

5. Sathish KM, Sneha K, Won SW, et al. Cinnamon zeylanicum bark extract and powder mediated green synthesis of nanocrystalline silver particles and its bactericidal activity. Colloids Surf B Biointerfaces. 2009;73:332-338. doi:10.1016/j.colsurfb.2009.06.005

6. Safaepour M, Shahverdi AR, Shahverdi HR, et al. Green synthesis of small silver nanoparticles using geraniol and its cytotoxicity against fibrosarcoma-Wehi 164. Avicenna J Med Biotechnol. 2009;1:111-115.

7. Thakkar KN, Mhatre SS, Parikh RY. Biological synthesis of metallic nanoparticles. Nanomedicine. 2010;6:257-262. doi:10.1016/j. nano.2009.07.002

8. Lakshmanan G, Sathiyaseelan A, Kalaichelvan P, Murugesan K. Plant-mediated synthesis of silver nanoparticles using fruit extract of Cleome viscosa L.: assessment of their antibacterial and anticancer activity. Karbala Int J Mod Sci. 2018;4(1):61-68. doi:10.1016/j. kijoms.2017.10.007

9. Sánchez-Navarro M, Ruiz-Torres CA, Niño-Martínez N, et al. Cytotoxic and bactericidal effect of silver nanoparticles obtained by green synthesis method using annona muricata aqueous extract and functionalized with 5-fluorouracil. Bioinorg Chem Appl. 2018;2018:8. doi:10.1155/2018/6506381

10. Elella MHA, Mohamed RR, Abdel-Aziz MM, Sabaa MW. Green synthesis of antimicrobial and antitumor N, N, N-trimethyl chitosan chloride/poly (acrylic acid)/silver nanocomposites. Int $J$ Biol Macromol. 2018;111:706-716. doi:10.1016/j.ijbiomac.2018.01.055

11. Palem RR, Ganesh SD, Kroneková Z, Sláviková M, Saha N, Sáha P. Green synthesis of silver nanoparticles and biopolymer nanocomposites: a comparative study on physico-chemical, antimicrobial and anticancer activity. Bull Mate Sci. 2018;41(2):55. doi:10.1007/ s12034-018-1567-5

12. Dadashpour M, Firouzi-Amandi A, Pourhassan-Moghaddam M, et al. Biomimetic synthesis of silver nanoparticles using Matricaria chamomilla extract and their potential anticancer activity against human lung cancer cells. Mater Sci Eng C. 2018;92:902-912. doi:10.1016/j. msec.2018.07.053

13. Baharara J, Ramezani T, Hosseini N, Mousavi M. Silver nanoparticles synthesized coating with Zataria multiflora leaves extract induced apoptosis in HeLa cells through p53 activation. IJPR. 2018;17(2):627.

14. Oves M, Aslam M, Rauf MA, et al. Antimicrobial and anticancer activities of silver nanoparticles synthesized from the root hair extract of Phoenix dactylifera. Mater Sci Eng. 2018;89:429-443. doi:10.1016/j.msec.2018.03.035

15. Gamal AAE, AlSaid MS, Raish M, et al. Beetroot (Beta vulgaris L.) extract ameliorates gentamicin-induced nephrotoxicity associated oxidative stress, inflammation, and apoptosis in rodent model. Mediators Inflamm. 2014;2014:983952. doi:10.1155/2014/983952 
16. Lee JH, Kim YS, Song KS, et al. Bio persistence of silver nanoparticles in tissues from Sprague-Dawley rats. Part Fibre Toxicol. 2013;1(10):36. doi:10.1186/1743-8977-10-36

17. Gurunathan S, Han JW, Eppakayala V, Jeyaraj M, Kim JH. Cytotoxicity of biologically synthesized silver nanoparticles in MDA-MB-231 human breast cancer cells. Biomed Res Int. 2013;2013:535796. doi:10.1155/2013/535796

18. Han JW, Gurunathan S, Jeong JK, et al. Oxidative stress mediated cytotoxicity of biologically synthesized silver nanoparticles in human lung epithelial adenocarcinoma cell line. Nanoscale Res Lett. 2014;9 (1):459. doi:10.1186/1556-276X-9-459

19. Hsin YH, Chen CF, Huang S, Shih TS, Lai PS, Chueh PJ. The apoptotic effect of nano-silver is mediated by a ROS and JNK-dependent mechanism involving the mitochondrial pathway in NIH3T3 cells. Toxicol Lett. 2008;179(3):130-139. doi:10.1016/j. toxlet.2008.04.015

20. Jeong JK, Gurunathan S, Kang MH, et al. Hypoxia-mediated autophagic flux inhibits silver nanoparticle-triggered apoptosis in human lung cancer cells. Sci Rep. 2016;6:21688. doi:10.1038/srep21688

21. Erdogan O, Abbak M, Demirbolat GM, et al. Green synthesis of silver nanoparticles via Cynara scolymus leaf extracts: the characterization, anticancer potential with photodynamic therapy in MCF7 cells. PLoS One. 2019;14(6):e0216496. doi:10.1371/journal.pone.0216496

22. Alarifi S, Ali D, Alkahtani S. Oxidative stress-induced DNA damage by manganese dioxide nanoparticles in human neuronal cells. Biomed Res Int. 2017;2017:5478790. doi:10.1155/2017/5478790

23. Alarifi S, Ali D, Alkahtani S. Nanoalumina induces apoptosis by impairing antioxidant enzyme systems in human hepatocarcinoma cells. Int J Nanomedicine. 2015;10(1):3751-3760. doi:10.2147/IJN. S82050

24. Alzahrani F, Khadijah M, Ali D, Alarifi S. Apoptotic and DNA-damaging effects of yttria- stabilized zirconia nanoparticles on human skin epithelial cells. Int J Nanomedicine. 2019;14:7003-7016. doi: $10.2147 /$ IJN.S212255

25. Bradford MM. A rapid and sensitive method for the quantitation of microgram quantities of protein utilizing the principle of protein dye binding. Anal Biochem. 1976;72:248-254. doi:10.1016/00032697(76)90527-3

26. Ohkawa H, Onishi N, Yagi K. Assay for lipid peroxidation in animal tissue by thiobarbituric acid reaction. Anal Biochem. 1979;95:351-358. doi:10.1016/0003-2697(79)90738-3

27. Ali D, Nagpure NS, Kumar S, Kumar R, Kushwaha B. Genotoxicity assessment of acute exposure of chlorpyrifos to freshwater fish channa punctatus (Bloch) using micronucleus assay and alkaline single-cell gel electrophoresis. Chemosphere. 2008;71(10):1823-1831. doi:10.1016/j. chemosphere.2008.02.007

28. Baker MA, Assis SL, Higa OZ, Costa I. Nanocomposite hydroxyapatite formation on Ti-13Nb-13Zr alloy exposed in a MEM cell culture medium and the effect of $\mathrm{H} 2 \mathrm{O} 2$ addition. Acta Biomater. 2009;5(1):63-75. doi:10.1016/j.actbio.2008.08.008

29. Kaja S, Payne AJ, Naumchuk Y, Koulen P. Quantification of lactate dehydrogenase for cell viability testing using cell lines and primary cultured astrocytes. Curr Protoc Toxicol. 2017;72:2.26.1. doi: $10.1002 /$ cptx.21

International Journal of Nanomedicine

\section{Publish your work in this journal}

The International Journal of Nanomedicine is an international, peerreviewed journal focusing on the application of nanotechnology in diagnostics, therapeutics, and drug delivery systems throughout the biomedical field. This journal is indexed on PubMed Central, MedLine, CAS, SciSearch ${ }^{\mathbb{R}}$, Current Contents ${ }^{\mathbb{R}} /$ Clinical Medicine, $^{2}$
30. Bova MP, Tam D, McMahon G, Mattson MN. Troglitazone induces a rapid drop of mitochondrial membrane potential in liver HepG2 cells. Toxicol Lett. 2005;155:41-50. doi:10.1016/j.toxlet.2004.08.009

31. Basavaraj KH. Nanotechnology in medicine and relevance to dermatology: present concepts. Indian J Dermatol. 2012;57(3):169-174. doi:10.4103/0019-5154.96186

32. Moosa AA, Ridha AM, Al-Kaser M. Process parameters for green synthesis of silver nanoparticles using leaves extract of aloe vera plant. Int J Multi Curr Res. 2015;3:966-975.

33. Anastas PT, Warner JC. Green Chemistry: Theory and Practice. New York: Oxford University Press; 1998.

34. Kou J, Varma RS. Beet juice utilization: expeditious green synthesis of noble metal nanoparticles (Ag, $\mathrm{Au}, \mathrm{Pt}$, and $\mathrm{Pd}$ ) using microwaves. RSC Adv. 2012;2:10283-10290. doi:10.1039/c2ra21908e

35. Burdușel AC, Gherasim O, Grumezescu AM, Mogoantă L, Ficai A, Andronescu E. Biomedical applications of silver nanoparticles: an up-to-date overview. Nanomaterials (Basel). 2018;8(9):681. doi:10.3390/nano8090681

36. Jiang Q, Yu S, Li X, Ma C, Li A. Evaluation of local anesthetic effects of lidocaine-Ibuprofen ionic liquid stabilized silver nanoparticles in Male Swiss mice. $J$ Photochem Photobiol B. 2018;178:367-370. doi:10.1016/j.jphotobiol.2017.11.028

37. Soni N, Dhiman RC. Phytochemical, anti-oxidant, larvicidal, and antimicrobial activities of castor (Ricinus communis) synthesized silver nanoparticles. Chin Herb Med. 2017;9:289-294. doi:10.1016/ S1674-6384(17)60106-0

38. Kaur A, Goyal D, Kumar R. Surfactant mediated interaction of vancomycin with silver nanoparticles. Appl Surf Sci. 2018;449:23-30. doi:10.1016/j.apsusc.2017.12.066

39. Petrov PD, Yoncheva K, Gancheva V, Konstantinov S, Trzebicka B. Multi-functional block copolymer nano-carriers for co-delivery of silver nanoparticles and curcumin: synthesis and enhanced efficacy against tumor cells. Eur Polym J. 2016;81:24-33. doi:10.1016/j. eurpolymj.2016.05.010

40. N J R, Vali DN, Rani M, Rani SS. Evaluation of antioxidant, antibacterial and cytotoxic effects of green synthesized silver nanoparticles by Piper longum fruit. Mater Sci Eng C. 2014;34:115-122. doi:10.1016/j.msec.2013.08.039

41. Mousavi B, Tafvizi F, Bostanabad SZ. Green synthesis of silver nanoparticles using Artemisia turcomanica leaf extract and the study of anti-cancer effect and apoptosis induction on gastric cancer cell line (AGS). Artif Cells Nanomed Biotechnol. 2018;46(S1):S499_ S510. doi:10.1080/21691401.2018.1430697

42. Wang TY, Libardo MDJ, Angeles-Boza AM, Pellois JP. Membrane oxidation in cell delivery and cell killing applications. ACS Chem Biol. 2017;12(5):1170-1182. doi:10.1021/acschembio.7b00237

43. Can K, Rinne CM, Rehling P, et al. Neuronal redox-imbalance in Rett Syndrome affects Mitochondria as Well as Cytosol, and is accompanied by intensified mitochondrial $\mathrm{O}_{2}$ consumption and ROS Release. Front Physiol. 2019. doi:10.3389/fphys.2019.00479

44. Grober U, Kisters K, Adamietz IA. Vitamin D in oncology: update 2015. Med Monatsschr Pharm. 2015;38(12):512-516.
Journal Citation Reports/Science Edition, EMBase, Scopus and the Elsevier Bibliographic databases. The manuscript management system is completely online and includes a very quick and fair peer-review system, which is all easy to use. Visit http://www.dovepress.com/ testimonials.php to read real quotes from published authors. 